\title{
A Student Perspective on Low English Proficiency in Oman
}

\author{
Rahma Al-Mahrooqi ${ }^{1}$ \\ ${ }^{1}$ Sultan Qaboos University, Oman \\ Correspondence: Rahma Al-Mahrooqi, Sultan Qaboos University, P.O. Box 42, Muscat 123, Oman. E-mail: \\ ralmahrooqi@gmail.com
}

Received: August 18, 2012 Accepted: September 11, 2012 Online Published: November 19, 2012

doi:10.5539/ies.v5n6p263

URL: http://dx.doi.org/10.5539/ies.v5n6p263

\begin{abstract}
The Omani government attaches great importance to English in the education of Omani youth and their preparation for a multicultural world of employment. It has therefore poured large resources into English language teaching in the nation's schools, colleges and universities. Unfortunately, these efforts have not yielded gains proportionate to this investment. Students continue to graduate from schools with inadequate English language proficiency and the majority therefore require remedial or intensive courses in a "foundation" program before beginning tertiary level study.

Based on a student perspective, this study investigated the above problem. Using data from focus groups and personal reports (based on a qualitative questionnaire) from 100 tertiary education students, it found that the major factors involved were as follows: ineffective teachers, inadequate curricula, uninterested students, limited exposure to English outside the classroom, unsupportive parents, a poor school system, and peer-group discouragement. Participants suggested a number of solutions and especially encouraging students to learn English by showing them its international status and its importance for their future education and employment.
\end{abstract}

Keywords: poor language proficiency, Oman, school graduates, factors

\section{Introduction}

As is often claimed, globalization has turned the world into a small village. With interaction between people from different nationalities increasing, boundaries become flimsier, making effective communication ever more critical. Meanwhile, English has emerged as the world's great lingua franca (Crystal, 1992, 2002; Graddol, 2003, Canagarajah, 2006). It is the language of information science, commerce, medicine, aviation, diplomacy, peacekeeping, trade, technology, and the internet. Hence, countries everywhere have recognized the importance of including English in their education systems, beginning even in the early school days of their young learners (Graddol, 2003). The number of students learning English as a foreign language currently exceeds the combined number of its native speakers [the inner circle, as Kachru $(1982,2005)$ termed it] and its second language speakers (the outer circle).

In Oman, English teaching has been given special attention since 1970 when His Majesty Sultan Qaboos Bin Said ascended the throne (Al-Mahrooqi \& Tuzlukova, 2010; Tuzlukova \& Al-Mahrooqi, 2010). It is seen as a key element in the development of the country and its effective integration into the modern world. At school level, from 1970 to 1998, English was taught from the fourth grade onwards, giving pupils nine years of instruction in the language before entering higher education. During the academic year 1998-1999, however, a program called Basic Education was begun in 17 Omani public schools. English instruction now began in grade one, increasing the number of years of tuition to twelve. The older system is now referred to as General Education. To enhance students' opportunities to acquire the language, the government provided major funding for both systems, but unfortunately this too has produced only meager results. The majority of higher education entrants still need extra tuition in English (Al-Issa, 2011) and find it very difficult to secure work because the private sector, for example, often requires very good English in its prospective employees (Al-Mahrooqi, 2012a; Al-Mahrooqi \& Asante, 2010). It is essential, therefore, to understand why public school graduates are poor at English, since this will reduce investment in Foundation Programs and produce higher education graduates with a level of proficiency required by the local and international job market (Altbach, 2010).

\section{The Study}

The study's main aim was to answer the following two questions: 
1) Why are so many Omani high school graduates weak in English?

2) What can be done to reduce the problem?

\section{Method}

The study followed an exploratory research design, which gave participants an opportunity to express their opinions unreservedly. It could explore the lived-through experiences (Khan, 2012) of EFL students by uncovering their views on how they were taught English in school and what affected their learning of it.

To encourage a free expression of ideas, a qualitative questionnaire (see appendix) and follow-up focus groups were used to examine students' school experience. These two instruments complemented each other. While the questionnaire gave vital information, however, some students provided only basic comments when answering it. Nevertheless, the discussions provided more detailed information about the factors that led to low English proficiency. The questionnaire was very simple, merely asking students, in the manner of providing a self-report, to answer the two research questions and to reflect on how they and their peers at school had learnt English. The discussions enabled them to elaborate on their thoughts.

\section{Sample}

A hundred students from Sultan Qaboos University took part in the study - 32 males and 68 females. Fifty-six came from the College of Education and the rest from the following colleges: Science (6), Arts and Social Sciences (11), Economics and Political Sciences (9), Agriculture and Marine Sciences (4), Engineering (3), Law (7), and Medicine and Health Sciences (4). Student majors included English, Translation, English Literature, Earth Science, Tourism, Finance, Water technology, Mass communication, Accounting, Geography, General law, Management, Mathematics, Technology (IT), Chemistry, General Arts, Biotechnology, and Civil Engineering. It is worth mentioning that 15 students were pre-majors since they were either first- or second-year students in science-based colleges. As for distribution across their years of college study, one participant was from the $6^{\text {th }}$ year, 22 from the $5^{\text {th }}, 39$ from the fourth, 21 from the $3^{\text {rd }}, 7$ from the $2^{\text {nd }}$ and 10 from the first. All had graduated from public schools, though a few had received some private education before entering government-run schools.

Participation in the study was voluntary and because of her female gender the researcher was able to contact more female than male students.

\section{Procedures}

To recruit as many participants as possible, a snowball technique was used (Cheng \& Dorniye, 2006). Many of the researcher's students from three different classes took part and were helpful in finding other students willing to participate. Though the target was 200 participants, and more than 200 questionnaires were distributed, only 100 were completed. The discussions were held with two of the three classes that took part in the study.

\section{Data Analysis}

Students' responses to the questionnaire were carefully read and factors cited as contributing to low English proficiency were tabulated. Frequency of mention for each factor was registered to see which factors was the most prevalent. Examples illustrating each factor were noted from either the questionnaire or from the focus group discussion notes. The study produced valuable data, whose full potential use is beyond the scope of this paper.

\section{Results and Discussion}

The table below illustrates the frequency of factors causing public school graduates' weakness in English, according to the participants. Each factor is a category including a set of reasons showing why students regard it as a cause of the problem under investigation. 
Table 1. Frequency of factors causing low English proficiency among school graduates

\begin{tabular}{lll}
\hline No. & Reasons & Percentage/Frequency \\
\hline 1. & Teachers & 85 \\
2. & Curriculum & 80 \\
3. & Students themselves & 70 \\
4. & Limited exposure to English and lack of practice outside the classroom & 24 \\
5. & Parents and the social context & 23 \\
6. & The system and the school environment & 15 \\
7. & Having careless and unmotivated friends & 2 \\
\hline
\end{tabular}

The table clearly shows that $85 \%$ of students thought that teachers are the major cause of their low level of English. The reasons can be summarized as follows:

1) Teachers are not well-prepared or qualified. They use old-fashioned, traditional teaching methods and styles, which are boring for students. There is a gap between teacher preparation programs and curriculum philosophies.

2) Teachers are asked to teach in a certain way as they are guided by the teachers' book.

3) Teachers' English proficiency is low and they do not work to improve this. Since most teachers confine themselves to the curriculum, they lose their competence in English.

4) Teachers in the lower grades are often very weak in English.

5) Teachers who graduated from private colleges or universities are especially ill-prepared and their English is weaker than their counterparts' who graduated from state-run universities and colleges.

6) Teachers use very simple language in the classroom.

7) Most teachers depend solely on the textbook.

8) Teachers' main concern is to finish the assigned curriculum.

9) Teaching methods stimulate only lower order thinking and cognitive skills.

10) Teachers do not care about their students and are not motivated to teach. They do not work honestly because they teach only for their pay.

11) Some teachers use Arabic when teaching English. In fact, some teach English in Arabic!

12) Non-Omani teachers know little about their students' backgrounds, and so do not understand them.

13) Non-Omani teachers come with various accents, which are hard for students to understand.

14) Some teachers focus on the best students in class, ignoring the struggling ones.

15) Teachers do not encourage students to care about English and to change their negative attitudes towards the language.

16) Many teachers do not speak in English with their students outside the classroom.

17) The Ministry of Education is not doing a good job of supervising teachers, which leaves teachers to their own devices.

18) Teachers get fed up quickly and give up when they do not get an immediate response from their students.

The complaints about teachers are connected in one way or another, pedagogic and linguistic inadequacy figuring prominently among them. Many English teachers seem not to care about their profession or about improving, or even maintaining, their own level of proficiency. In fact, recent research has found that Omani EFL teachers generally experience language attrition, a loss due to various factors, including environments where English is not spoken as a first language (Al-Mahrooqi \& Sultana, 2012). In addition, the education system seems to discourage flexibility by requiring teachers to follow a pre-set curriculum and teaching methods, which students find uninteresting. Low teacher motivation is reflected in their lack of care for those who are weak and despondent. Yet showing students care was suggested as the key strategy EFL teachers should use to motivate their students (Al-Mahrooqi, Abrar ul-Hassan \& Asante, 2012; Asante, Al-Mahrooqi \& Abrar 
ul-Hassan, 2012; Cheng \& Dörnyei, 2006). Instead, however, the study suggests that they do not try to change student attitudes or improve their motivation. They themselves avoid using English outside the classroom and so are poor models for their students. Moreover, the Ministry of Education seems to ignore effective supervision, student guidance, and any system of accountability. Hence, teachers are neither well-prepared pedagogically nor professionally well-monitored.

In terms of the curriculum as a major cause of poor language proficiency, the following findings emerged:

1) Learning and teaching are dependent on the textbooks, which are boring. The topics covered are unimportant, inappropriate and uninteresting. They do not relate to student interests. Hence they are not helpful as the input students receive from them is neither engaging nor comprehensible.

2) There is a lack of communicative tasks and so students mostly sit passively in the classroom. There is little chance to practice speaking inside or outside class.

3) English is taught too formally. There is no variety in terms of class activities.

4) The curriculum does not cover all the skills adequately.

5) The amount of time (per period) allocated to English is inadequate.

6) English is not a discipline. There is no information or content to learn.

7) English is only a school subject. It does not exist beyond the classroom.

8) There is too much focus on grammar.

9) There is much to cover but most of it is useless.

10) Teaching materials are inadequate. There is little to supplement the textbook and in general schools have few books.

11) In Basic Education, the first grade does not effectively ground students in English. In General Education, English is only taught from grade four.

12) Both the Basic and General Education curricula are weak.

13) There is not enough focus on reading as no time is specified for this skill.

14) There are no tutorials or remedial lessons for weak students.

15) Textbook are not progressively graded.

16) The curriculum is too difficult for weak students and yet unchallenging for good ones.

Other reasons relating to the curriculum include its inflexibility and uneven skills coverage. Reading and speaking seem to be ignored, despite their crucial importance for student competence, with one providing input and the other output opportunities. Reading is also an essential skill for academic success, generating abundant content and vocabulary, and providing examples of language use. This of course can have positive effects on writing. Indeed, research has found that good readers are often good writers. Research has also shown, however, that Omani school graduates are poor writers (Al-Mahrooqi \& Tuzlukova, 2012). The unbalanced curriculum seems to be text-book dependent and caters ill for weak students, who are soon left behind. Similarly, because the curriculum targets mainly average students, it fails to challenge the good ones.

Despite the inception of Basic Education in 1998/1999 (Ministry of Education, 2006), which introduced new curricula, schools still lack supplementary materials and facilities necessary for success in English (Moates, 2006). A comprehensive study could usefully examine existing shortages and thus indirectly help to improve levels of students' English language proficiency.

Seventy per cent of participants blamed students themselves for their low level of English. Hence the following comments:

1) Students do not like English; indeed they hate it. They perceive it negatively and so are not interested in it.

2) Some students hate Westerners.

3) Students learn English at a late stage in life, unlike their mother tongue.

4) Students consider English unimportant. They are unaware of its importance. They do not value it. For them, it is not as important as the other subjects.

5) Students are afraid of English and consider it too difficult to learn. 
6) Students are careless about their English. They do not want to learn it or improve in it. They are not keen to speak it or practice it.

7) Students are irresponsible. They do not take English seriously. The English period is like a free lesson. Some study it only for exams.

8) Some students cheat in exams.

9) Some students like English but depend too much on their teachers.

10) Students do not focus on understanding and grammar but simply memorize vocabulary.

A quick glance at these comments shows the centrality of negative attitudes (Asante, Al-Mahrooqi \& Abrar-ul-Hassan, 2012). Most school students are not interested in or motivated to learn English because of their negative perceptions of it and of westerners. They see it as difficult and not as important as other subjects. They lack sufficient autonomy to study it, work at it only for exams, and then cheat in order to pass them. They also lack appropriate study skills and depend on memorization, a strategy transferred from their culture and traditional Arab way of learning.

As for the lack of exposure to English outside the classroom, which limits English usage and practice for authentic purposes in natural settings, participants commented as follows:

1) There are no opportunities to practice English outside the classroom.

2) There is very limited contact with either native speakers or speakers of English as a second language.

3) When students attempt to speak English outside the classroom, they are mocked.

4) Extracurricular activities that require the use of English are either absent or insufficient. There are very few English clubs in the schools.

5) There are no events at school that encourage the use of English.

6) There are no competitions involving the use of English.

7) Teachers do not use English outside the classroom.

8) There are no field trips to places where English is spoken.

9) There are not enough English books in the schools.

10) There are no libraries or bookshops that sell good English books.

11) English is not used at home.

12) In summer, there are no English courses available.

There is, then, a paucity of opportunities to use English outside the classroom. Even in school - beyond the classroom - students are denied a chance to speak or practice the language with their teachers, most of whom want to converse in Arabic after the English period. Students attempting to practice their language with other students are mocked by them because of overall negative attitudes and a particular, long-standing perception that those who try to speak English outside the classroom are showing off (Al-Mahrooqi, 2012b). There is minimal English output from students, therefore, partly because of a discouraging environment. This is a problem for many Omani English teachers keen to use their language beyond the classroom, and one they list as a factor in their own language attrition (Al-Mahrooqi \& Sultana, 2012).

Parental attitudes and the wider social context are also relevant because they reflect little awareness of the importance of English for school students' future academic and professional success - attitudes mirroring the students' own. At best parents are satisfied if their children simply obtain a passing grade in English, and some even discourage their children from learning and excelling in it, seeing it as foreign and potentially harmful. Hence, then, a lack of supervision of homework or concern about academic progress in general.

The educational system and school environment also manifest a lack of appreciation for English. Though much is expected of students, unhelpful school administrations do not try to create an atmosphere that fosters English language acquisition. Classrooms are often cramped and crowded, containing mixed levels of language proficiency, and there is a general dearth of facilities and incentives for keen learners.

Active discouragement comes from linguistically incompetent peers who mock their friends' efforts to use their English outside the classroom. Unmotivated themselves, they are poor models for their friends. Nor does there seem to be much in-class opportunity for pair or group work, which creates an uncooperative atmosphere not conducive to language learning. 
These seven key factors and the reasons associated with them clearly explain why Omani students graduating from state-run schools are weak in English. However, the findings embodying them come from 100 students enrolled at SQU. A more in-depth and nuanced investigation, involving a much wider range of stakeholders, is required to uncover further elements at work behind this serious and costly academic problem.

Among possible solutions to it, the following are those most frequently mentioned by respondents:

1) From the very beginning encourage students to study English independently by showing them how important English is for their future educational and occupational success. This can be done, for example, by sending them short messages on their cell-phones, publishing relevant articles on school bulletin boards, arranging stimulating talks on the topic by visiting speakers, and holding lively discussions.

2) Teachers should show students that they care about them and their progress in learning English. They should not undermine students' confidence but instead keep building it.

3) Increase the number of English classes and the length of the English period. Also the Ministry of Education could consider teaching either maths or science in English and thus increase exposure to the language.

4) Hire qualified teachers only. Before appointment, they should be tested to ascertain their preparedness in terms of methodology and language competence.

5) Provide in-service training and professional development programs for teachers to ensure they maintain their language competence.

6) Offer incentives, such as gifts and certificates, to good students.

7) Allocate more class time for discussion and conversation.

8) Vary class activities to make lessons interesting and fun. For example, use games, puzzles, TV, videos, films, cartoons, documentaries, and stories.

9) Emphasize reading by including novels and keeping a small library of English books in each classroom. Also, specify a definite reading time in all English lessons.

10) The Ministry of Education should devise a better supervision system.

11) Engage students in extra-curricular activities that require the use of English.

12) Prepare teachers well enough to deal with weak students. Introduce remedial classes for poor performers and dare to fail them if they do not meet set objectives.

13) Offer summer courses in English to encourage continued exposure to the language.

14) Focus on the early years because they are the foundation for future success.

15) Ensure strict invigilation during exams to prevent cheating.

16) Evaluate the curriculum from time to time and remove those policies that hinder teachers from doing a good job.

17) Establish a connection between English and other subjects by teaching important terminology and using texts of common interest.

18) Establish a strong connection between parents and schools.

19) Schools should specify one day a month on which all students and staff must speak English.

20) Group students in class according to their level of proficiency.

Not all these solutions might be viable, but many are important enough for serious consideration. Certainly, changing negative attitudes towards English (Arnold, 1999; Tomlinson, 1998a; 1998b; 2003) by reducing student anxiety about learning it, cultivating confidence in their abilities, caring about their progress, encouraging them to study the language and showing them its importance are essential if any improvement is to occur in school graduates' English proficiency. Training teachers effectively and revising curricula are also very important since these two are major constituents of the learning process. Providing more exposure to English (input) (Maley, 1994; Tomlinson, 1998a, 2007; Mitsutomi, n.d.) and encouraging language use beyond the classroom are also very important. Practitioners agree that using a language in interpersonal and social contexts is vital for its successful acquisition (Cummins \& Swain, 1986). Similarly (Swain, 1993), learning a language cannot progress swiftly without encouraging students to use it in various contexts and natural settings. No one enjoys dull classes and hence the importance of the suggestion about varying class activities and methods to cater for different learning styles (Brown, 2000; Oxford, 1994). 


\section{Conclusion}

The study clearly revealed many important factors underlying school students' low English language proficiency. They should be addressed as soon as possible if any progress in solving the problem is to be achieved. However, because the findings were gleaned from a group of university students, the topic should be investigated from the perspectives of other stakeholders. Two research instruments were used, but not all the data was reported in this study due to practical and logistical reasons. The remaining data will be used for future work on a more nuanced examination of the views expressed by participants in this study.

\section{References}

Al-Issa, A. (2011). Advancing English language teaching research in Gulf Cooperation Council States universities. MJAL, 3(2), 60-77.

Al-Mahrooqi, R., \& Tuzlukova, V. (2012). Meeting employers' needs: Communication skills in Omani tertiary education. Proceedings of Oman Symposium on Management "Inspiring Oman Towards New Horizons, March 2012 (pp. 208-231). Ibra: Ibra College of Technology.

Al-Mahrooqi, R. (2012a). English communication skills: How are they taught at schools and universities in Oman. English Language Teaching.

Al-Mahrooqi, R. (2012b). Reading Literature in English: Challenges Facing Omani College Students. Asian EFL Journal, 57, 24-51. Retrieved from http://asian-efl-journal.com/journal-2012/

Al-Mahrooqi, R., \& Sultana, T. (2012). FL attrition among Omani teachers of English: Teachers' perceptions. In A. Mahmoud and R. Al-Mahrooqi (Eds.), Issues in Teaching and Learning English as a Foreign Language in the Arab World (pp. 47-66). Al-Khoudh: Sultan Qaboos University Academic Publication Board.

Al-Mahrooqi, R., \& Asante, C. (2010). Promoting autonomy by fostering a reading culture. In R. Al-Mahrooqi \& V. Tuzlukova (Eds.). The Omani ELT Symphony: Maintaining Linguistic and Socio-cultural Equilibrium (pp. 477-494). Muscat: Sultan Qaboos University Academic Publication Board.

Al-Mahrooqi, R., \& Tuzlukova, V. (2010). Introduction: Cultural perspectives and ELT in Oman. In R. Al-Mahrooqi \& V. Tuzlukova (Eds.). The Omani ELT Symphony: Maintaining Linguistic and Socio-cultural Equilibrium (pp. 13-29). Muscat: Sultan Qaboos University Academic Publication Board.

Al-Mahrooqi, R., Abrar-ul-Hassan, S., \& Asante, C. (2012). Analyzing the use of motivational strategies by EFL teachers in Oman. Malaysian Journal of ELT Research, 8(1), 36-76. Retrieved from www.melta.org.my

Altbach, P. (2010). Notes on the future of SQU: Comparative perspectives. In Towards a Long-term Strategic Plan for Sultan Qaboos University: Proceedings of the International Workshop (9-10 November 2010) (pp. 3-9). Muscat: Sultan Qaboos University Press.

Arnold, J. (Ed.). (1999). Affect in Language Learning. Cambridge: Cambridge University Press.

Asante, C., Al-Mahrooqi, R., \& Abrar-ul-Hassan, S. (2012). The effects of three teacher variables on the use of motivational strategies in EFL Instruction in Oman. TESOL Arabia Perspectives, 19(1), 12-22. Retrieved from www.tesolarabia.org

Brown, H. D. (2000). Principles of Language Learning and Teaching (4 ed.). New York: Longman.

Canagarajah, S. (2006). Changing communicative needs, revised assessment objectives: Testing English as an international language. Language Assessment Quarterly, 3(3), 229-242. http://dx.doi.org/10.1207/s15434311laq0303_1

Cheng, H. F., \& Dörnyei, Z. (2007). The Use of motivational strategies in language instruction: The case of EFL Teaching in Taiwan. Innovation in Language Learning and Teaching, 1(1), 153-174. http://dx.doi.org/10.2167/illt048.0

Crystal, D. (1992). An Encyclopedic Dictionary of Language and Languages. Oxford: Blackwell Publishers.

Crystal, D. (2002). English in the New World. Babylonia 1/2002, 16-17.

Cummins, J., \& Swain, M. (1986). Bilingualism in Education. New York: Longman.

Graddol, D. (2003). The Future of English. The British Council.

Jiang, X. (2006). Suggestions: What should ESL students know? System, 34, 36-54. http://dx.doi.org/10.1016/j.system.2005.02.003 
Kachru, B. (1982). Models for non-native Englishes. In B. B. Kachru (Ed.). The Other Tongue. Urbana: Urbana University of Illinois.

Kachru, B. (2005). Asian English: Beyond the Canon. Hong Kong: Hong Kong University Press.

Khan, S. (2012). Factors Affecting the Motivation of Expatriate English as a Foreign Language (EFL) Teachers in the Sultanate of Oman. Unpublished PhD dissertation. University of Exeter, U.K.

Maley, A. (1994). Play it again Sam: A role of repetition. Folio, 1(2), 4-5.

Ministry of Education. (2006). From Access to Success: Education for All (EFA) in the Sultanate of Oman 1970-2005. Sultanate of Oman: Ministry of Education.

Mitsutomi, M. (n.d.). Some fundamental principles of language teaching and learning. Retrieved from http://www.aeservices.net/English/Language-Learning-Mitsutomi.pdf on April 5, 2012.

Moates, J. (2006). Final Report. The Sultanate of Oman: Ministry of Education.

Moody, J. (2009). A neglected aspect of ELT in the Arabian Gulf: Who is communication between? In Zhang, L. J., R. Rubdy, \& Alsagoff, L. (Eds.). Englishes and Literatures-in-English in a Globalized world: Proceedings of the $13^{\text {th }}$ International Conference on English in Southeast Asia (pp. 99-119). Singapore: National Institute of Education, Nanyang Technological University.

Oxford, R. (1994). Language Learning Strategies. An Update. CAL Online Digest. October 1994.

Swain, M. (1993). The output hypothesis: Just speaking and writing aren't enough. The Canadian Modern Language Review, 50, 158-164.

Tomlinson, B. (1998a). Introduction. In B. Tomlinson (Ed.). Materials Development in Language Teaching (pp. 1-24). Cambridge: Cambridge University Press.

Tomlinson, B. (1998b). Affect and the coursebook. IATEFL Issues, 145, 20-21.

Tomlinson, B. (2003). Humanizing the coursebook. In B. Tomlinson (Ed.). Developing Materials for Language Teaching (pp. 162-173). London: Continuum Press.

Tomlinson, B. (2007). Introduction: Some similarities and differences between L1 and L2 acquisition and development. In B. Tomlinson (Ed.). Language Acquisition and Development: Studies of Learners of First and Other Languages (pp. 1-12). London: Continuum Press.

Tuzlukova, V., \& Al-Mahrooqi, R. (2010). Culture-based curriculum dimensions. In R. Al-Mahrooqi \& V. Tuzlukova (Eds.). The Omani ELT Symphony: Maintaining Linguistic and Socio-cultural Equilibrium (pp. 33-70). Muscat: Sultan Qaboos University Academic Publication Board. 


\section{Appendix}

A Student Perspective on Low English Proficiency

Dr. Rahma Al-Mahrooqi

Dear Student

This is a preliminary investigation of factors causing low English proficiency among government school graduates. I will be grateful to you if you answered the following questions in as much detail as possible. Your answers will remain confidential and will only be used for research purposes. Thank you.
A. Background Information

Gender:

College:

Major:

Year at college:

B. Please Answer the Following Questions

1. Why are so many public school graduates weak in English?

2. What can be done to improve English proficiency level among public school graduates? 